\title{
Environment, Management, and Genetic Contributions to Maize Kernel Hardness and Grain Yield
}

\author{
Aníbal Cerrudo,^ Dionisio Martinez, Natalia G. Izquierdo, Alfredo G. Cirilo, M. Paula Laserna, \\ Lucio Reinoso, Oscar Valentinuz, Celsa Balbi, and Fernando H. Andrade
}

\begin{abstract}
Dry milling performance of maize (Zea mays L.) is directly related to kernel hardness. This study assessed the contribution of maize hybrid and crop growing condition on kernel hardness and grain yield. Three hybrids that fully explore the available genetic variability for kernel hardness were planted at different environments across the Argentinean cropping area. At each environment, early and late planting dates and supplemental fertilization were evaluated. Kernel coarse-to-fine ratio was used as an indicator of kernel hardness. Coarse-to-fine ratio ranged from 2.0 to $7.0 \mathrm{~g} \mathrm{~g}^{-1}$, grain yield ranged from 494 to $1391 \mathrm{~g} \mathrm{~m}^{-2}$, and both were affected by hybrid and growing conditions. Hybrid ranking was stable across growing conditions; however, differences among hybrids in kernel coarse-to-fine ratio and grain yield increased when growing condition favored kernel hardness and grain yield. Growing condition explained $>60 \%$ of total variability in coarseto-fine ratio and grain yield. Fertilization management had significant but small influence on assessed variables. In contrast, the interaction between planting date and environment was the major determinant of kernel coarse-to-fine ratio and grain yield. Delayed planting consistently reduced kernel hardness at high-latitude locations. Potential photosynthetic source during maize reproductive period explained $37 \%$ of the variation in kernel coarse-to-fine ratio. Environment and agronomic management should be considered together with the hybrid in the design of maize production strategies oriented to end-use quality.
\end{abstract}

A. Cerrudo, D. Martinez, N.G. Izquierdo, and F.H. Andrade, Facultad de Ciencias Agrarias, Univ. Nacional de Mar del Plata (FCA, UNMdP), Argentina; A. Cerrudo, A.G. Cirilo, L. Reinoso, O. Valentinuz, and F.H. Andrade, Instituto Nacional de Tecnología Agropecuaria (INTA), Argentina; N.G. Izquierdo, M.P. Laserna, and F.H. Andrade, Consejo Nacional de Investigaciones Científicas y Técnicas (CONICET), Argentina; L. Reinoso, Dep. de Ciencias Exactas, Naturales y de Ingeniería, Univ. Nacional de Río Negro, Argentina; C. Balbi, Facultad de Ciencias Agrarias, Univ. Nacional del Noreste, Corrientes, Argentina. Received 14 Dec. 2016. Accepted 20 June 2017. *Corresponding author (cerrudo. anibal@inta.gob.ar). Assigned to Associate Editor Jeffrey Coulter.

Abbreviations: IPAR, incident photosynthetic active radiation; RUE, radiation use efficiency.

$\mathrm{M}$ AIZE (Zea mays L.) food products such as breakfast cereals, snacks, and other textured ingredients are processed by the dry milling industry (Orthoefer et al., 2003). The dry milling industry demands grain that yields a high proportion of large grits during the milling process (Lee et al., 2007). Dry milling performance of maize is directly associated with kernel hardness, which can be expressed as its mechanical resistance to milling (Wu, 1992; Holding and Larkins, 2006). Kernel hardness also influences several kernel nutritive properties, grinding power requirements, and dust formation (Paulsen et al., 2003). Kernel coarse-to-fine ratio is an excellent indicator of maize kernel hardness (Robutti et al., 2000; Fox and Manley, 2009; Blandino et al., 2013). A high value of coarse-to-fine ratio is a typical attribute of hard kernels and is associated with elevated dry milling yields.

In the first half of the last century, Argentina grew almost exclusively flint hybrids that produced hard grain. During this time, Argentinean maize breeding programs considered both kernel quality and yield. After that period, local breeding efforts were mainly focused on grain yield. The progressive introduction of dent germplasm raised grain yield (Luque et al., 2006)

Published in Crop Sci. 57:2788-2798 (2017).

doi: 10.2135/cropsci2016.12.0997

(C) Crop Science Society of America | 5585 Guilford Rd., Madison, WI 53711 USA All rights reserved. 
but concurrently reduced kernel hardness (Eyhérabide et al., 2004). Accordingly, maize kernel hardness has been mainly associated with the hybrid (i.e., flint, semi-dent, and dent hybrids; Louis-Alexandre et al., 1991; Dombrink-Kurtzman and Bietz, 1993; Robutti et al., 1997, 2000; Duarte et al., 2005). However, other studies report that the growing condition also affect maize kernel hardness (Eyhérabide et al., 2004; Blandino et al., 2013).

Understanding the role of growing conditions on maize kernel hardness is important due to great climatic diversity across the maize cropping area in Argentina, which extends from 25 to $40^{\circ} \mathrm{S}$ (Aramburu Merlos et al., 2015) and from subtropical to cool-temperate climates (Hall et al., 1992; Caffera and Berbery, 2006). Agronomic management also affects growing conditions to which crops are exposed, yet few studies have assessed the effect of environment and crop management on maize kernel hardness attributes (Cirilo et al., 2011; Gerde et al., 2016; Tamagno et al., 2016).

Late plantings of maize have become a frequent practice in Argentina, and currently more than half of maize is cultivated under delayed planting (PAS, 2016). Farmers are implementing late planting dates to reduce the risk of water deficit during the critical flowering period (Maddonni, 2012). Planting delay also leads to a deterioration of the growing conditions during maize reproductive period in which kernel hardness is determined (Cirilo et al., 2011) due to decreased air temperature, incident radiation, and consequently crop photosynthetic source (Cirilo and Andrade, 1994; Bonelli et al., 2016).

Nutrient availability and therefore fertilization management is also a determinant of maize kernel hardness (Duarte et al., 2005). However, there is discrepancy regarding fertilization requirements for maximizing kernel hardness in relation to those requirements to maximize grain yield. A recent study concluded that $\mathrm{N}$ requirements to maximize kernel hardness are greater than those needed to maximize grain yield (Tamagno et al., 2016), in contrast with the findings reported by Cirilo et al. (2011).

Knowledge about the stability of kernel hardness across diverse growing conditions for different hybrids can help in hybrid choice according to the environment and agronomic management. The concept of genotype response to growing conditions has been widely used to analyze grain yield and could be also useful to analyze quality-related traits like kernel hardness (Peterson et al., 1992).

Grain quality determines much of the value of maize to the dry milling industry, whereas grain yield determines much of its value to the farmer (Tamagno et al., 2015). A production strategy oriented to kernel hardness also needs to consider its effects on grain yield. The objectives of this study were to asses: (i) the contribution of maize hybrid and growing conditions on kernel coarseto-fine ratio and grain yield, (ii) the effects of planting date and fertilization management on kernel coarse-tofine ratio and grain yield across the maize cropping area of Argentina, and (iii) kernel coarse-to-fine ratio response to growing conditions among hybrids representative of the range in genetic variability for kernel hardness.

\section{MATERIALS AND METHODS Cultivars, Crop Management, and Site Information}

Sixteen experiments were performed at five locations across the Argentinean main maize-cropping area during the 2007 to 2008, 2008 to 2009, 2009 to 2010, and 2010 to 2011 growing seasons. Sites, from south to north, were the research stations of the National Institute for Agricultural Technology (INTA) at Viedma $\left(40^{\circ} 49^{\prime} \mathrm{S}, 63^{\circ} 00^{\prime} \mathrm{W}\right)$, Río Negro Province, Balcarce $\left(37^{\circ} 50^{\prime} \mathrm{S}, 58^{\circ} 15^{\prime} \mathrm{W}\right)$ and Pergamino $\left(33^{\circ} 53^{\prime} \mathrm{S}, 60^{\circ} 34^{\prime} \mathrm{W}\right)$, Buenos Aires Province, Paraná $\left(31^{\circ} 43^{\prime} \mathrm{S}, 60^{\circ} 32^{\prime} \mathrm{W}\right)$, Entre Ríos Province, and the experimental field of the University of Noreste at Corrientes $\left(27^{\circ} 27^{\prime} \mathrm{S}, 58^{\circ} 49^{\prime} \mathrm{W}\right)$, Corrientes Province (Fig. 1). Soil and climate details are presented in Table 1.

Each experiment was a randomized complete block with a split-plot treatment arrangement replicated three times. Treatments included two planting dates that constituted the main plot and a factorial arrangement of two levels of fertilization management and three maize hybrids that constituted the subplot. All experiments evaluated an early and a late planting date with the exception of Corrientes 2009 to 2010, Corrientes 2010 to 2011, and Paraná 2010 to 2011 for which only early planting date was evaluated (Table 1). Fertilization management consisted of a control oriented to maximize grain yield and a



Fig. 1. Map of Argentina indicating the sites where experiments were conducted. 
Table 1. Experimental information, including site, soil classification, experiment initiation (year), soil organic matter (OM), soil $\mathrm{pH}$, previous crop (antecessor), and planting date treatment (planting). Dates of planting, silking, and physiological maturity (maturity), mean air temperature ( $T_{\text {mean }}$ ), mean daily incident photosynthetically active radiation (IPAR), and estimated potential crop growth per unit area during maize reproductive period (i.e., crop potential photosynthetic source [source]).

\begin{tabular}{|c|c|c|c|c|c|c|c|c|c|c|c|c|}
\hline Site & $\begin{array}{l}\text { USDA soil } \\
\text { classification }\end{array}$ & Year & $\mathrm{pH}$ & OM & Antecessor & Planting & $\begin{array}{l}\text { Planting } \\
\text { date }\end{array}$ & $\begin{array}{l}\text { Silking } \\
\text { date }\end{array}$ & Maturity date & $T_{\text {mean }}$ & IPAR & Source \\
\hline & & & & $\%$ & & & & & & ${ }^{\circ} \mathrm{C}$ & $M J m^{-2} d^{-1}$ & $\mathrm{~g} \mathrm{~m}^{-2}$ \\
\hline \multirow[t]{2}{*}{ Corrientes } & \multirow{2}{*}{$\begin{array}{c}\text { Fine loamy mixed } \\
\text { hyperthermic } \\
\text { Udipsamments }\end{array}$} & 2009 & - & - & Maize & Early & 4 Oct. 2009 & 10 Dec. 2009 & 25 Jan. 2010 & 27.1 & 11.3 & 2875 \\
\hline & & 2010 & 5.5 & 1.4 & Maize & Early & 14 Sept. 2010 & 6 Dec. 2010 & 21 Jan. 2011 & 26.0 & 11.2 & 2700 \\
\hline \multirow[t]{7}{*}{ Paraná } & \multirow{7}{*}{$\begin{array}{l}\text { Fine mixed thermic } \\
\text { Aquic Argiudolls }\end{array}$} & 2007 & 6.6 & 2.8 & Maize & Early & 18 Oct. 2007 & 28 Dec. 2007 & 16 Feb. 2008 & 24.9 & 11.9 & 2924 \\
\hline & & & & & & Late & 10 Dec. 2007 & 17 Feb. 2008 & 14 Apr. 2008 & 22.2 & 8.8 & 2099 \\
\hline & & 2008 & 6.5 & 2.5 & Maize & Early & 10 Oct. 2008 & 16 Dec. 2008 & 3 Feb. 2009 & 25.2 & 11.8 & 2896 \\
\hline & & & & & & Late & 5 Jan. 2009 & 2 Mar. 2009 & 24 Apr. 2009 & 22.1 & 8.7 & 1933 \\
\hline & & 2009 & 6.8 & 2.8 & Maize & Early & 5 Oct. 2009 & 17 Dec. 2009 & 4 Feb. 2010 & 25.3 & 11.4 & 2815 \\
\hline & & & & & & Late & 9 Dec. 2009 & 9 Feb. 2010 & 5 Apr. 2010 & 23.3 & 9.3 & 2302 \\
\hline & & 2010 & 6.6 & 2.5 & Maize & Early & 18 Oct. 2010 & 28 Dec. 2010 & 15 Feb. 2011 & 25.3 & 11.8 & 2900 \\
\hline \multirow[t]{8}{*}{ Pegamino } & \multirow{8}{*}{$\begin{array}{l}\text { Silty clay loam } \\
\text { Typic Argiudolls }\end{array}$} & 2007 & 6.3 & 2.5 & Maize & Early & 17 Oct. 2007 & 30 Dec. 2007 & 25 Feb. 2008 & 23.8 & 11.6 & 3052 \\
\hline & & & & & & Late & 13 Dec. 2007 & 11 Feb. 2008 & 12 Apr. 2008 & 21.0 & 9.1 & 2143 \\
\hline & & 2008 & 6.8 & 2.5 & Maize & Early & 22 Oct. 2008 & 24 Dec. 2008 & 18 Feb. 2009 & 24.0 & 12.1 & 3186 \\
\hline & & & & & & Late & 15 Dec. 2008 & 13 Feb. 2009 & 18 Apr. 2009 & 21.9 & 9.3 & 2457 \\
\hline & & 2009 & 7.1 & 2.5 & Maize & Early & 6 Oct. 2009 & 21 Dec. 2009 & 19 Feb. 2010 & 23.8 & 11.4 & 3174 \\
\hline & & & & & & Late & 15 Dec. 2009 & 15 Feb. 2010 & 12 Apr. 2010 & 20.1 & 9.5 & 1928 \\
\hline & & 2010 & 7.3 & 2.3 & Maize & Early & 13 Oct. 2010 & 1 Jan. 2011 & 1 Mar. 2011 & 22.4 & 11.7 & 2927 \\
\hline & & & & & & Late & 15 Dec. 2010 & 12 Feb. 2011 & 18 Apr. 2011 & 19.3 & 9.3 & 2060 \\
\hline \multirow[t]{8}{*}{ Balcarce } & \multirow{8}{*}{$\begin{array}{l}\text { Silty clay loam } \\
\text { Typic Argiudolls }\end{array}$} & 2007 & 5.9 & 5.6 & Maize & Early & 18 Oct. 2007 & 15 Jan. 2008 & 20 Mar. 2008 & 20.3 & 9.7 & 2333 \\
\hline & & & & & & Late & 11 Dec. 2007 & 21 Feb. 2008 & 26 Apr. 2008 & 17.7 & 7.6 & 1468 \\
\hline & & 2008 & 6.1 & 5.6 & Maize & Early & 20 Oct. 2008 & 8 Jan. 2009 & 20 Mar. 2009 & 21.8 & 11.2 & 3238 \\
\hline & & & & & & Late & 8 Dec. 2008 & 15 Feb. 2009 & 30 Apr. 2009 & 19.1 & 8.2 & 2038 \\
\hline & & 2009 & 6.2 & 5.5 & Wheat & Early & 15 Oct. 2009 & 6 Jan. 2010 & 20 Mar. 2010 & 20.7 & 10.7 & 2967 \\
\hline & & & & & & Late & 9 Dec. 2009 & 15 Feb. 2010 & 23 Apr. 2010 & 17.0 & 8.0 & 1510 \\
\hline & & 2010 & 6.1 & 5.5 & Soybean & Early & 18 Oct. 2010 & 11 Jan. 2011 & 15 Mar. 2011 & 21.2 & 11.2 & 2767 \\
\hline & & & & & & Late & 6 Dec. 2010 & 10 Feb. 2011 & 15 Apr. 2011 & 19.4 & 9.1 & 2008 \\
\hline \multirow[t]{4}{*}{ Viedma } & \multirow{4}{*}{$\begin{array}{l}\text { Fine silty clay } \\
\text { thermic Aridic } \\
\text { Gypsiusterts }\end{array}$} & 2009 & 7.9 & 4.5 & Pasture & Early & 22 Oct. 2009 & 15 Jan. 2010 & 28 Mar. 2010 & 20.5 & 10.9 & 2882 \\
\hline & & & & & & Late & 14 Dec. 2009 & 16 Feb. 2010 & 21 Apr. 2010 & 17.6 & 8.3 & 1572 \\
\hline & & 2010 & 8.2 & 4.4 & Maize & Early & 23 Nov. 2010 & 1 Feb. 2011 & 10 Apr. 2011 & 20.3 & 10.1 & 2521 \\
\hline & & & & & & Late & 10 Dec. 2010 & 12 Feb. 2011 & 16 Apr. 2011 & 19.3 & 9.1 & 1953 \\
\hline
\end{tabular}

supplemental fertilization treatment that received supplemental fertilization with $\mathrm{N}$ and $\mathrm{S}$ compared with the control.

The experimental fields were prepared with conventional tillage, consisting of disking in June and disking and field cultivation in September. Previous crops are listed in Table 1. Soil extractable P (Bray II) in the 0 - to 20 -cm soil layer was always $\geq 18 \mathrm{mg} \mathrm{kg}^{-1}$ before experiment initiation. Additionally, $150 \mathrm{~kg}$ $\mathrm{ha}^{-1}$ of calcium triple superphosphate $\left[\mathrm{Ca}\left(\mathrm{H}_{2} \mathrm{PO}_{4}\right) \mathrm{H}_{2} \mathrm{O}\right]$ was broadcast and incorporated preplanting to supply $30 \mathrm{~kg} \mathrm{P} \mathrm{ha}^{-1}$. Crop $\mathrm{K}$ requirement was assumed to be largely covered by soil $\mathrm{K}$ reserves (Moscatelli et al., 2001). Soil-test $\mathrm{K}$ in the $0-$ to $20-\mathrm{cm}$ soil layer was $\geq 136 \mathrm{mg} \mathrm{kg}^{-1}$ of extractable $\mathrm{K}$ before initiation of all experiments. Soil-test $\mathrm{S}$ in the $0-$ to $20-\mathrm{cm}$ soil layer was $\geq 6 \mathrm{mg} \mathrm{SO}-\mathrm{S} \mathrm{kg}^{-1}$ before initiation of all experiments, with the exception of Pergamino during 2007 to 2008, where $\mathrm{SO}_{4}-\mathrm{S}$ was $2 \mathrm{mg} \mathrm{kg}^{-1}$ in that soil layer. Soil S availability generally does not limit maize grain yield in the evaluated soils, and therefore S fertilizer is usually not applied for maize (Pagani et al., 2009).

Fertilization management for control treatment involved $\mathrm{N}$ applied as urea $\left[\mathrm{CO}\left(\mathrm{NH}_{2}\right)_{2}\right]$ at the six-leaf collar stage of maize development (Ritchie et al., 1997). Nitrogen doses were defined to maximize grain yield and were derived from local adapted models (Melchiori et al., 1996; Sainz Rozas et al., 2000; Mistrorigo and Valentinuz, 2004) based on the preside dress soil $\mathrm{N}$ test (Magdoff et al., 1984). Urea was applied at 60 to $90 \mathrm{~kg} \mathrm{~N}$ $\mathrm{ha}^{-1}$ in bands on the inter-row soil surface and was immediately incorporated into the soil by irrigation. The supplemental fertilization treatment received a supplemental application of $100 \mathrm{~kg}$ $\mathrm{N} \mathrm{ha}^{-1}$ and $40 \mathrm{~S} \mathrm{~kg} \mathrm{ha}^{-1}$ using a mixture of urea and ammonium sulfate $\left[\left(\mathrm{NH}_{4}\right)_{2} \mathrm{SO}_{4}\right]$ at the tasseling stage, which occurred 5 to $7 \mathrm{~d}$ before silking (Ritchie et al., 1997). The fertilizer mixture was placed in a band on the inter-row soil surface and was immediately incorporated into the soil by irrigation.

Three maize hybrids representative of the locally available range for kernel hardness, adapted to the whole cropping area of Argentina and widely adopted by Argentinean farmers, were selected for evaluation: (i) the flint hybrid M522 (Dow AgroSciences), which had kernels among the hardest of 20 Argentinean hybrids previously characterized by Eyhérabide et al. (2004) and also characterized as having hard kernels by Tamagno et al. (2016); (ii) the semident hybrid Cóndor (Syngenta), which had an intermediate hardness level when characterized by Eyhérabide et al. (2004) and characterized as semihard by Cirilo et al. (2011); and (iii) the dent hybrid DK190 (Monsanto), characterized as a 
soft-kernel hybrid (Tamagno et al., 2016). The hybrids M522, Cóndor, and DK190 were released in 2002, 2000, and 2003, respectively (INASE, 2016). These hybrids have similar growing season requirements to physiological maturity (Tamagno et al., 2015). Relative maturity ratings were 123, 121, and 120 for the flint, semident, and dent hybrids, respectively.

All experiments were hand planted with three seeds per hill and thinned to 7.5 plants $\mathrm{m}^{-2}$ at the three-collar stage (Ritchie et al., 1997). Experimental units consisted of five rows $0.7 \mathrm{~m}$ apart and $10.0 \mathrm{~m}$ long $\left(35 \mathrm{~m}^{2}\right)$. Water stress was prevented by complementing precipitation with sprinkler irrigation to keep available soil water content $>50 \%$ in the uppermost $1.0 \mathrm{~m}$ of soil throughout the growing season. Weeds were controlled by a combination of pre- and postemergence herbicides, which varied with location and year. Plots were also hand weeded to control escaped weeds. Insect damage was prevented with $0.24 \mathrm{~L} \mathrm{ha}^{-1}$ of chlorpytifos [0,0-diethyl-0-(3,5,6-trichloro-2-pyridinyl) phosphorothioate] at maize emergence (Ritchie et al., 1997).

\section{Measurements}

Daily maximum and minimum air temperatures were obtained from weather stations located $<0.5 \mathrm{~km}$ from the experimental sites. Daily incident photosynthetic active radiation (IPAR) was obtained from satellite derived solar data (van Wart et al., 2013; NASA-POWER, 2017) based on the work of Aramburu Merlos et al. (2015) that indicated good fit between data derived from satellite and those obtained using a radiometer. Crop reproductive growth stages (Ritchie et al., 1997) were determined for each plot at 3- to 5-d intervals. Silking was recorded as the date when $50 \%$ of the plants had at least one emerged silk from the husks. Physiological maturity was recorded as the date when $50 \%$ of the sampled plants had kernels at $75 \%$ milk-line stage at the mid-portion of the ear (Hunter et al., 1991). Harvest took place within 1 wk after the record of physiological maturity. All plants in $4.0 \mathrm{~m}$ of the three central rows $\left(8.4 \mathrm{~m}^{2}\right)$ from each plot were manually collected and ears were dehusked and dried at room temperature to 140 to $160 \mathrm{~g} \mathrm{~kg}^{-1}$ moisture content before being shelled with a static sheller (Almaco). Grain was weighted, and grain moisture was determined with a Tesma A-79 moisture meter (Tesma SAIC). Grain yield was calculated at $0 \mathrm{~g} \mathrm{~kg}^{-1}$ moisture content.

Maize kernel coarse-to-fine ratio was determined as described by Pomeranz et al. (1986). A sample of $50 \mathrm{~g}$ of whole kernels from each plot was ground for $15 \mathrm{~s}$ in a Stein laboratory mill (Seedboro Equipment Company). Ground kernels were sifted at full speed for $60 \mathrm{~s}$ in a mechanical sifter (Chopin) equipped with circular sieves of 1.0- and 0.5-mm mesh openings. Quantities of coarse material retained by the $1.0-\mathrm{mm}$ sieve and of fine material passing through the $0.5-\mathrm{mm}$ sieve were weighed. The kernel coarse-to-fine ratio was estimated as the weight ratio between the coarse and the fine fractions.

\section{Data Analysis}

Data were analyzed with descriptive statistics, ANOVA, and regression analysis using $\mathrm{R}$ (De Mendiburu, 2009) and Prism 5.0 (GraphPad, 2007) software at $P \leq 0.01$. A first analysis was performed to determine the effects of hybrid, growing condition,

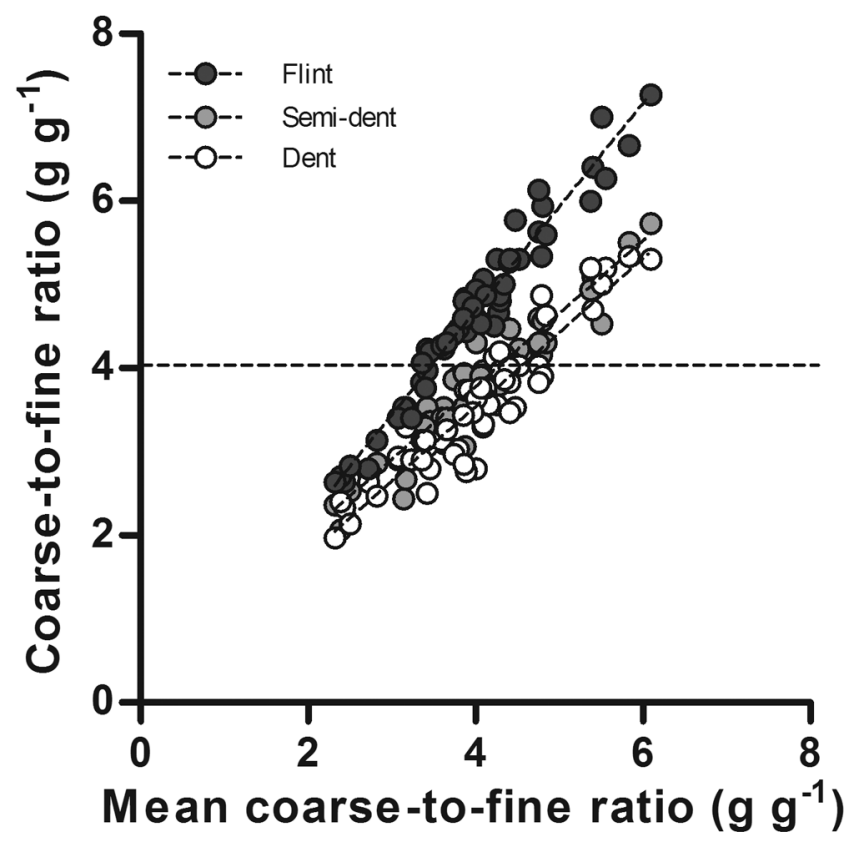

Fig. 2. Kernel coarse-to-fine ratio for three maize hybrids representative of different endosperm classes as a function of mean coarse-to-fine ratio for different growing conditions (environment $\times$ agronomic management). Mean coarse-to-fine ratio of a growing condition is the average kernel coarse-tofine ratio of the three hybrids for each combination of site-year, planting date, and fertilization management. The horizontal line indicates coarse-to-fine ratio threshold for premium quality by the European standard (Serignese and Pescio, 1995). Flint: $y=$ $1.24 x-0.28, R^{2}=0.96, P<0.001$; semident: $y=0.87 x+0.29$, $R^{2}=0.90, P<0.001$; dent: $y=0.89 x-0.01, R^{2}=0.85, P<$ 0.001. Slope 95\% confidence intervals: flint $=1.17-1.31$, semident $=0.79-0.95$, dent $=0.78-0.98$.

Table 2. Results from ANOVA for kernel coarse-to-fine ratio and grain yield analyzed over hybrids and growing conditions.

\begin{tabular}{|c|c|c|c|c|c|c|c|c|c|}
\hline \multirow[b]{2}{*}{ Source of variation } & \multirow[b]{2}{*}{ df } & \multicolumn{4}{|c|}{ Kernel coarse-to-fine ratio } & \multicolumn{4}{|c|}{ Grain yield } \\
\hline & & SS† & $P>F$ & LSD & SS/TSS $\ddagger$ & SSt & $P>F$ & LSD & SS/TSS $\ddagger$ \\
\hline & & & & & $\%$ & & & & $\%$ \\
\hline Growing condition (G) & 57 & 378 & ** & - & 64 & $1,666,555,160$ & ** & - & 77 \\
\hline Hybrid $(\mathrm{H})$ & 2 & 128 & ** & - & 22 & $166,431,783$ & ** & - & 8 \\
\hline $\mathrm{H} \times \mathrm{G}$ & 114 & 44 & ** & 0.79 & 7 & $133,312,156$ & ** & 867 & 6 \\
\hline Residual & 348 & 42 & & & 7 & $202,847,372$ & & & 9 \\
\hline Total & & 592 & & & & $2,169,146,471$ & & & \\
\hline
\end{tabular}

** Significant at the 0.01 probability level.

† SS, sums of squares.

$\ddagger$ TSS, total sums of squares. 


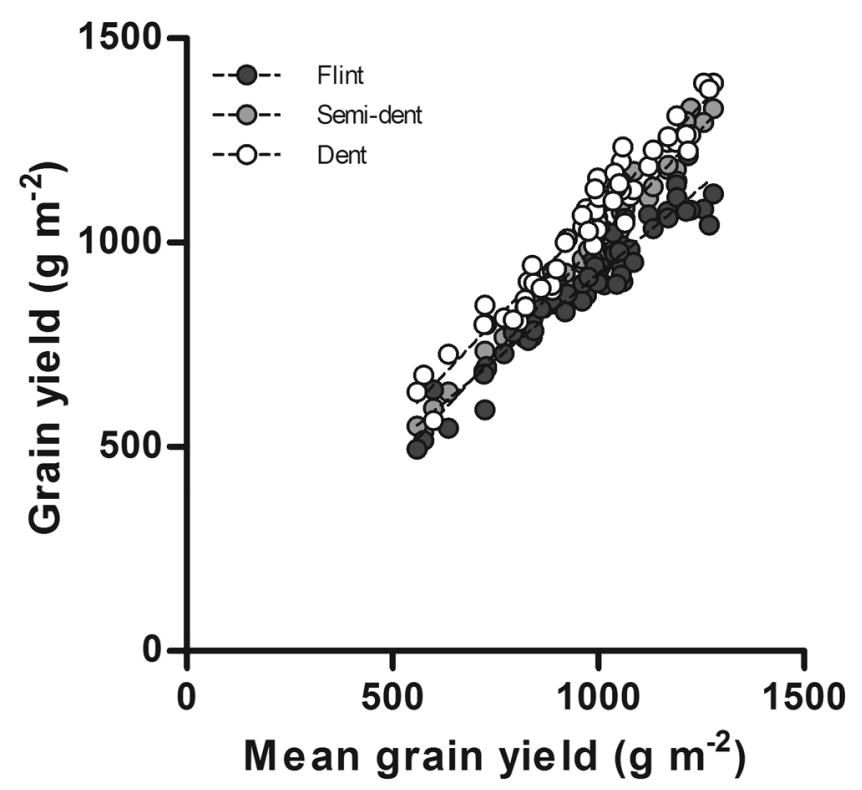

Fig. 3. Grain yield for three maize hybrids representative of different endosperm classes as a function of the mean grain yield for different growing conditions (environment $\times$ crop management). Mean yield of a growing condition is the average grain yield of the three hybrids for each combination of site-year, planting date, and fertilization management. Flint: $y=0.83 x+93.4, R^{2}=0.92, P<$ 0.001; semident: $y=1.10 x-99.8, R^{2}=0.96, P<0.001$; dent: $y=$ $1.07 x+6.3, R^{2}=0.95, P<0.001$. Slope $95 \%$ confidence intervals: flint $=0.76-0.90$, semident $=1.04-1.17$, dent $=1.00-1.14$. and their interaction (Table 2). Each combination of environment (site-year), planting date, and fertilization management was considered a growing condition. Additionally, the contribution of each source of variation to total variability was estimated as the ratio of its sum of squares and the total sums of squares.

A second analysis was performed to assess the response of kernel coarse-to-fine ratio and grain yield to variations in growing conditions for the different hybrids (Fig. 2 and 3). Kernel coarse-to-fine ratio and grain yield responses were estimated by the slope of the linear regression of coarse-to-fine ratio or grain yield of each hybrid in relation to the mean coarse-to-fine ratio or grain yield for the different growing conditions as described by Finlay and Wilkinson (1963). Differences in the response among hybrids were evaluated by comparing the confidence intervals of the slopes of these regressions equations.

A third analysis was performed to assess the effect and contribution of environment (site-year) and agronomic management to kernel coarse-to-fine ratio and grain yield (Tables 3 and 4). Analysis of variance was conducted across environments to evaluate the effects of planting date, fertilization management, and their interactions on kernel coarse-to-fine ratio and grain yield. Corrientes in 2009 to 2010 and 2010 to 2011 and Paraná in 2009 to 2010 were not included in the analysis because they lacked the late planting date. Hybrids were poled for this analysis based on the small proportion of variability accounted for by the non-crossover-type interaction between hybrid and growing condition reveled in the previous analysis. Fisher's LSD was applied to determine significant differences.

Table 3. Maize kernel coarse-to-fine ratio and grain yield for different environments (site-year) with early and late planting dates and two levels of fertilization management (control [cont.] and supplemental fertilization [fert.]). Each value is the average of three hybrids and three replications. ANOVA results and LSD values are given in Table 4.

\begin{tabular}{|c|c|c|c|c|c|c|c|c|}
\hline \multicolumn{2}{|c|}{ Environment } & \multirow[b]{2}{*}{ Planting date } & \multicolumn{3}{|c|}{ Coarse-to-fine ratio } & \multicolumn{3}{|c|}{ Grain yield } \\
\hline Site & Year & & Cont. & Fert. & Avg. & Cont. & Fert. & Avg. \\
\hline & & & & $-g^{-1}$ & 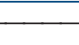 & 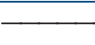 & $\mathrm{g} \mathrm{m}^{-2}$ & 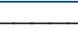 \\
\hline Paraná & 2007 & Early & 3.87 & 4.23 & 4.05 & 924 & 1060 & 992 \\
\hline Paraná & 2007 & Late & 4.27 & 4.47 & 4.37 & 998 & 1005 & 1002 \\
\hline Paraná & 2008 & Early & 4.10 & 4.80 & 4.45 & 599 & 721 & 660 \\
\hline Paraná & 2008 & Late & 3.40 & 4.10 & 3.75 & 560 & 576 & 568 \\
\hline Paraná & 2009 & Early & 4.00 & 4.40 & 4.20 & 844 & 1035 & 940 \\
\hline Paraná & 2009 & Late & 3.47 & 4.27 & 3.87 & 635 & 724 & 680 \\
\hline Pergamino & 2007 & Early & 3.60 & 3.90 & 3.75 & 1085 & 1077 & 1081 \\
\hline Pergamino & 2007 & Late & 4.50 & 4.80 & 4.65 & 962 & 1055 & 1008 \\
\hline Pergamino & 2008 & Early & 5.83 & 6.10 & 5.97 & 1044 & 1056 & 1050 \\
\hline Pergamino & 2008 & Late & 5.57 & 5.40 & 5.48 & 961 & 993 & 977 \\
\hline Pergamino & 2009 & Early & 4.40 & 4.73 & 4.57 & 1133 & 1169 & 1151 \\
\hline Pergamino & 2009 & Late & 4.30 & 4.83 & 4.57 & 887 & 888 & 887 \\
\hline Pergamino & 2010 & Early & 4.07 & 4.37 & 4.22 & 1064 & 1269 & 1166 \\
\hline Pergamino & 2010 & Late & 3.40 & 3.60 & 3.50 & 998 & 1056 & 1027 \\
\hline Balcarce & 2007 & Early & 3.13 & 3.17 & 3.15 & 1121 & 1168 & 1145 \\
\hline Balcarce & 2007 & Late & 2.40 & 2.40 & 2.40 & 970 & 1014 & 992 \\
\hline Balcarce & 2008 & Early & 4.43 & 4.73 & 4.58 & 975 & 1040 & 1008 \\
\hline Balcarce & 2008 & Late & 4.20 & 4.30 & 4.25 & 807 & 822 & 815 \\
\hline Balcarce & 2009 & Early & 5.50 & 5.37 & 5.43 & 1191 & 1189 & 1190 \\
\hline Balcarce & 2009 & Late & 2.83 & 2.70 & 2.77 & 839 & 830 & 835 \\
\hline Balcarce & 2010 & Early & 3.77 & 3.80 & 3.78 & 1255 & 1279 & 1267 \\
\hline Balcarce & 2010 & Late & 2.47 & 2.33 & 2.40 & 1001 & 998 & 1000 \\
\hline Viedma & 2009 & Early & 4.92 & 5.15 & 5.04 & 1244 & 1266 & 1255 \\
\hline Viedma & 2009 & Late & 3.43 & 3.33 & 3.38 & 771 & 729 & 750 \\
\hline Viedma & 2010 & Early & 3.83 & 3.97 & 3.90 & 1213 & 1224 & 1218 \\
\hline \multirow[t]{2}{*}{ Viedma } & 2010 & Late & 3.07 & 3.00 & 3.03 & 992 & 988 & 990 \\
\hline & & Average & 3.93 & 4.14 & & 953 & 1000 & \\
\hline
\end{tabular}


Table 4. Results from ANOVA for kernel coarse-to-fine ratio and grain yield analyzed over environments, planting dates, and fertilization treatments.

\begin{tabular}{|c|c|c|c|c|c|c|c|c|c|}
\hline \multirow[b]{2}{*}{ Source of variation } & \multirow[b]{2}{*}{ df } & \multicolumn{4}{|c|}{ Kernel coarse-to-fine ratio } & \multicolumn{4}{|c|}{ Grain yield } \\
\hline & & SSt & $P>F$ & LSD & SS/TSS & SSt & $P>F$ & LSD & SS/TSS \\
\hline & & & & & $\%$ & & & & $\%$ \\
\hline Environment $(E) \S$ & 12 & 222 & ** & - & 40 & $849,966,974$ & ** & - & 41.2 \\
\hline Planting date $(P)$ & 1 & 52 & ** & - & 9 & $466,301,344$ & ** & - & 22.6 \\
\hline Fertilization (F) & 1 & 5.3 & ** & 0.24 & 1 & $2,3198,616$ & ** & 389 & 1.1 \\
\hline Ex Block & 13 & 2.3 & ns & - & 0.4 & $16,396,825$ & ns & - & 0.8 \\
\hline$E \times P$ & 12 & 86 & $\star *$ & 0.62 & 15 & $202,307,453$ & ** & 1402 & 9.8 \\
\hline$P \times F$ & 1 & 0.1 & ns & - & 0.02 & $5,483,122$ & ns & - & 0.3 \\
\hline$E \times F$ & 12 & 6.6 & ns & - & 1 & $24,920,144$ & ns & - & 1.2 \\
\hline$E \times P \times F$ & 12 & 1.4 & ns & - & 0.3 & $12,405,857$ & ns & - & 0.6 \\
\hline Residual & 403 & 185 & & & 33 & $461,172,796$ & & & 22.4 \\
\hline Total & & 561 & & & & $2,062,153,131$ & & & \\
\hline
\end{tabular}

** Significant at the 0.01 probability level.

† SS, sums of squares.

$\ddagger$ TSS, total sums of squares.

§ Corrientes 2009 to 2010 and 2010 to 2011 and Paraná 2010 to 2011 were not included due to the lack of a late planting treatment.

If ns, not significant.

A fourth analysis was performed to compare the fertilization requirements for maximum kernel coarse-to-fine ratio in relation to those to maximize grain yield (Fig. 4). The association between kernel coarse-to-fine ratio and grain yield responses to supplemental fertilization was evaluated by linear regression analysis. The regression equation was also compared with the 1:1 equation model to assess proportionality between responses. The response of these variables to supplemental fertilization for each environment and planting date combination was estimated using Eq. [1] and pooled data across hybrids:

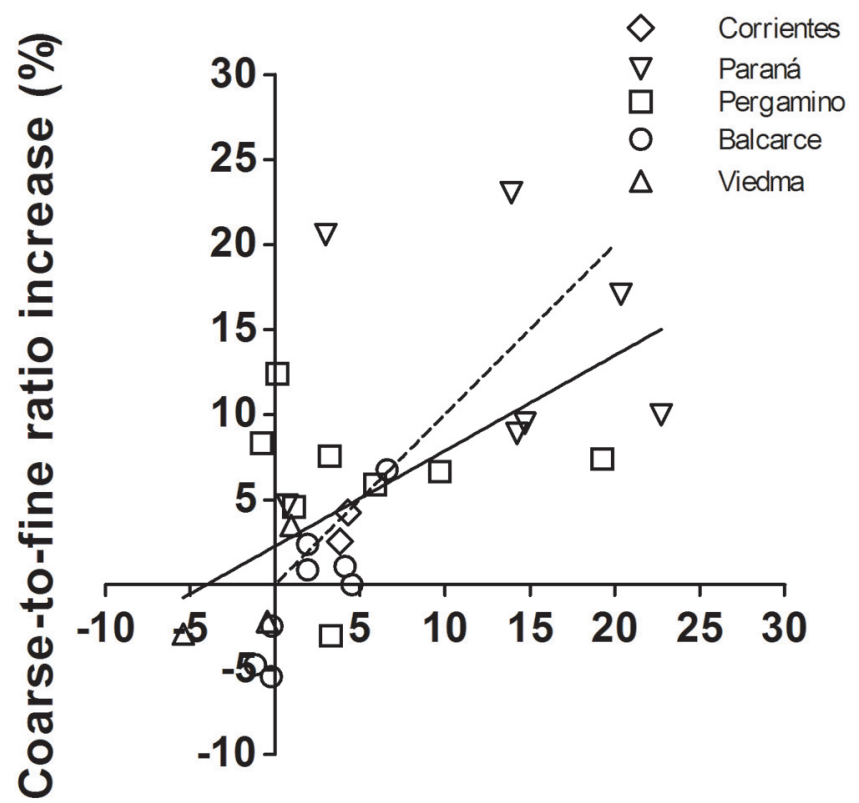

\section{Grain yield increase (\%)}

Fig. 4. Relative increase in maize kernel coarse-to-fine ratio and grain yield as a response to supplemental fertilization across environments and planting dates $\left(y=0.53 x+2.27, R^{2}=0.33, P\right.$ $=0.0012$ ). The dashed line represents the 1:1 relationship. Each value is the average of three hybrids and three replications.
Response $(\%)=$

$$
\frac{\text { (supplemental fertilization }- \text { control) }}{\text { control }} \times 100
$$

A fifth analysis was performed to integrate climate variables during maize reproductive period from silking to physiological maturity and to explore their relationship with kernel coarseto-fine ratio (Fig. 5). By adapting the net canopy photosynthesis model of Monteith (1972), potential photosynthetic source

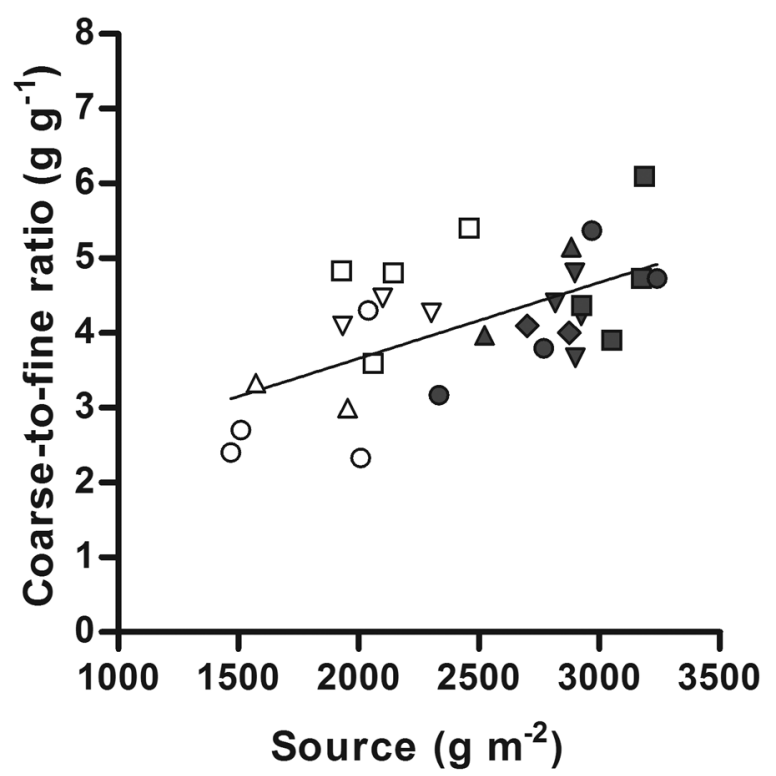

Fig. 5. Maize kernel coarse-to-fine ratio as a function of crop potential photosynthetic source (i.e., potential crop growth per unit area) from silking to physiological maturity. Early (filled symbols) and late (empty symbols) planting dates at different environments. Corrientes (diamonds), Paraná (inverted triangles), Pergamino (squares), Balcarce (circles), and Viedma (triangles). Each value is the average of three hybrids and three replications of the supplemental fertilization treatment. $y=1.0210^{-3} x-1603, R^{2}=$ 0.37, $P<0.001)$. 
during the crop reproductive period was estimated as potential crop growth from silking to physiological maturity (Table 1). This model was based on IPAR and estimated potential radiation use efficiency (RUE) using Eq. [2]:

$$
\text { Source } g=\operatorname{IPAR}\left(\mathrm{MJ} \mathrm{m} \mathrm{m}^{-2}\right) \times \operatorname{RUE}\left(\mathrm{g} \mathrm{MJ}^{-1}\right)
$$

Potential RUE was estimated as a function of mean air temperature $\left(T_{\text {mean }}\right)$ following the lineal relationship reported by Andrade et al. (1993) presented in Eq. [3]:

$$
\operatorname{RUE}\left(\mathrm{g} \mathrm{MJ}^{-1}\right)=0.27 T_{\text {mean }}-1.8
$$

The relationship between potential photosynthetic source for the different environments and planting dates and kernel coarse-to-fine ratio was assessed by linear regression analysis.

\section{RESULTS}

Silking and physiological maturity dates were not affected by the hybrid or the fertilization management in all experiments $(P \geq 0.091)$. Mean dates of silking and physiological maturity, mean air temperature, and mean daily IPAR during maize reproductive period for the different environments and planting dates are presented in Table 1. A wide range of growing conditions was generated by: (i) sites located on a north to south transect across the Argentinean maize growing area, from subtropical to template-cool areas (Fig. 1), (ii) interannual variability, (iii) contrasting planting dates combined with variation in thermal and radiative annual oscillation at each location, and (iv) different fertilization management treatments. The diverse growing conditions together with the contrasting hybrids resulted in kernel coarse-to-fine ratio that ranged from 2.0 to $7.0 \mathrm{~g} \mathrm{~g}^{-1}$ and grain yield that ranged from 494 to $1391 \mathrm{~g} \mathrm{~m}^{-2}$ (Fig. 2 and 3).

\section{Hybrid and Growing Condition Contribution}

Hybrid, growing condition (i.e., the combination of environment, planting date, and fertilization management), and their interaction affected kernel coarse-to-fine ratio and grain yield (Table 2). Hybrid explained 22 and 8\% of the variability in coarse-to-fine ratio and grain yield, respectively. Crop growing conditions explained 64 and $77 \%$ of total variability for coarse-to-fine ratio and grain yield, respectively. The interaction between hybrid and growing conditions explained a small proportion of total variability for coarse-to-fine ratio and grain yield for both variables $(\leq 8 \%)$.

Hybrid ranking for kernel coarse-to-fine ratio and grain yield were consistent across the different growing conditions (Fig. 2 and 3). Kernel coarse-to-fine ratio of the flint hybrid was always greater than or equal to that of the semident hybrid, whereas coarse-to-fine ratio of the semident hybrid was always greater than or equal to that of the dent hybrid. On average, kernel coarse-to-fine ratio of the flint hybrid was $8 \%$ greater than that of the semident hybrid, and the semident hybrid had a coarse-to-fine ratio that was $7 \%$ greater than that of the dent hybrid. The opposite trend was observed for grain yield (Fig. 3). On average, grain yield of the flint hybrid was $8 \%$ less than that of the semident hybrid and grain yield of the semident hybrid was $7 \%$ less than that of the dent hybrid.

\section{Hybrid Response to Growing Conditions}

The flint hybrid had a greater response of kernel coarseto-fine ratio to growing conditions than the semident and dent hybrids (Fig. 2). The slope of the regression equation between coarse-to-fine ratio and mean coarse-to-fine ratio at each growing condition was greater for the flint than for the semident and dent hybrids (1.24 vs. 0.89 and 0.87 , respectively; $P<0.001$ ). The flint hybrid had the weakest grain yield response to growing conditions (Fig. 3). The slope of the regression equation between grain yield and mean grain yield at each growing condition was less for the flint than semident and dent hybrids $(0.83$ vs. 1.07 and 1.10 , respectively; $P<0.001$ ). There was no relationship between kernel coarse-to-fine ratio and grain yield among growing conditions across hybrids $\left(R^{2}=\right.$ $0.03, P=0.12$ ).

\section{Environment and Agronomic Management Contribution}

Further analysis was performed to segregate the effects of growing condition factors (environment, planting date, and fertilization management) on kernel coarse-to-fine ratio and grain yield across hybrids (Table 4). Fertilization management affected kernel coarse-to-fine ratio and grain yield $(P \leq 0.001$, Tables 3 and 4$)$. Fertilization management explained $\sim 1 \%$ of the variability in coarse-to-fine ratio and grain yield (Table 4). On average, supplemental fertilization increased coarse-to-fine ratio and grain yield by $5 \%$ compared with the control (Table 3). There was a linear association between the magnitude of the responses of kernel coarse-to-fine ratio and grain yield to supplemental fertilization $\left(R^{2}=0.32, P=0.001\right.$, Fig. 4$)$, and this association was not different from a 1:1 function $(P=$ $0.037)$. Environment, planting date, and their interaction affected kernel hardness and grain yield $(P<0.001$, Table 4). Unlike fertilization management, environment and planting date together explained more than one-half of the total variability in kernel hardness (64\%) and grain yield (74\%).

With early planting, differences in kernel coarseto-fine ratio among environments were relatively small (Table 3) and coarse-to-fine ration was generally near or above dry milling industry requirements $\left(4 \mathrm{~g} \mathrm{~g}^{-1}\right.$; Serignese and Pescio, 1995). Kernel coarse-to-fine ratio always decreased with delayed planting at Viedma and Balcarce, except during 2008 to 2009. On average, delayed planting reduced kernel coarse-to-fine ratio by 27 and $29 \%$ at Viedma and Balcarce, respectively (Table 3). At low-latitude locations, the effect of planting date on coarse-to-fine 
ratio was not consistent and was less compared with that at high-latitude locations (Tables 3 and 4). At low-latitude locations, kernel coarse-to-fine ratio was generally above industry requirements, regardless of planting date (Fig. 5). Grain yield was reduced at all locations when planting date was delayed, except at Paraná in 2007 to 2008 and at Pergamino in 2007 to 2008 and 2008 to 2009 (Table 3). The average reduction in grain yield was 29, 21, 12 , and $13 \%$ at Viedma, Balcarce, Pargamino, and Paraná, respectively (Fig. 5). Kernel coarse-to-fine ratio for each combination of environment and planting date was associated with potential photosynthetic source during the maize reproductive period (Fig. 5).

\section{DISCUSSION}

Most previous studies that deal with maize kernel hardness were focused on the effect of hybrid (Robutti et al., 2000; Duarte et al., 2005; Gerde et al., 2016), and few have assessed the effects of the environment and agronomic management (Eyhérabide et al., 2004; Cirilo et al., 2011; Tamagno et al., 2016). This work extends these studies by combining contrasting hybrids (i.e., from flint to dent), environments, and agronomic management practices that allow evaluation across a wide range of growing conditions (Table 1; Fig. 2 and 3).

Kernel hardness, as indicated by kernel coarse-to-fine ratio, was consistently affected by hybrid across the wide range of growing conditions. Maximum kernel coarseto-fine ratio was always obtained with the flint hybrid (Table 2; Fig. 2). The difference in coarse-to-fine ratio between the flint and the dent hybrid was similar to that reported between the hardest and the softest Argentinean hybrids grouped by Eyhérabide et al. (2004). These results are also in accordance with recent studies that compared kernel hardness for different hybrids (Cirilo et al., 2011; Gerde et al., 2016; Tamagno et al., 2016). Additionally, we showed a differential response of kernel coarse-tofine ratio to growing conditions among hybrids. This response was greatest for the flint hybrid (Fig. 2). These results are in disagreement with the common belief that hybrids with harder kernels have greater stability across growing conditions, also indicated by Cirilo et al. (2011). According to current trading requirements (Serignese and Pescio, 1995), kernel coarse-to-fine ratio should be $>4.0 \mathrm{~g} \mathrm{~g}^{-1}$ to achieve the premium grade for the dry milling industry (Fig. 2). Using this threshold, the flint hybrid would have been classified as premium in $64 \%$ of the evaluated situations, whereas the semident and dent hybrids would have achieved that grade only in 28 and $16 \%$ of the situations, respectively (Fig. 2). Therefore, the hybrid with the hardest kernels had the greatest kernel coarse-to-fine response to the growing condition and attained industry requirements more frequently than the hybrids with softer kernels.
The flint hybrid consistently produced the least grain yield across growing conditions (Fig. 3), in agreement with previous studies (Brun and Dudley, 1989; Eyhérabide et al., 2004; Luque et al., 2006; Cirilo et al., 2011). These results are also in accordance with Tamagno et al. (2015), who reported that grain productivity of several flint hybrids is $\sim 80 \%$ of that for dents hybrids. They concluded that the main cause for this grain yield penalty in flint hybrids was reduced growth rate at flowering, which is the critical period for grain set (Andrade et al., 1999). The growing condition $\times$ hybrid interaction (Table 3 ) is demonstrated by an increase in kernel coarse-to-fine ratio and grain yield differences among hybrids when growing conditions favored an increase in kernel hardness and grain yield. The assessed hybrids are representative of different hardness classes; however, results from additional hybrids are needed to validate these findings.

Growing condition was the main source for variability in coarse-to-fine ratio and grain yield (67 and $74 \%$ of total sums of squares, respectively; Table 3). These results highlight the roll of the environment and agronomic management on kernel hardness. This is one of the major contributions of the present study, especially taking into account the diversity of agroclimatic regions and agronomic managements for maize production that this study represents.

Among growing condition determinants, fertilization management had a relative small effect on kernel coarse-to-fine ratio and grain yield compared with the environment and planting date (Tables 3 and 4). These results are supported by other studies in temperate (Bauer and Carter, 1986; Kniep and Manson, 1991; Gerde et al., 2016) and tropical (Duarte et al., 2005) climates, which reported that an increase in $\mathrm{N}$ availability increases kernel hardness, but the effect is small and likely influenced by soil nutrient availability. The responses of both variables were compared in an attempt to establish differences in fertilization requirements to maximize kernel coarse-to-fine ratio and grain yield (Fig. 4). A more than proportional response for kernel coarse-to-fine ratio than for grain yield would indicate that fertilization requirements to maximize coarse-to-fine ratio are greater than those to maximize grain yield, as proposed by Gerde et al. (2016). Responses to supplemental fertilization for both variables were directly but weakly associated, and the regression equation did not differ from a 1:1 function. These results do not support differential fertilization requirements for maximizing kernel hardness and grain yield. The weakness of this relationship indicates that more detailed studies are needed to advance in the understanding of fertilization thresholds for these variables.

The majority of the total variation in kernel coarseto-fine ratio and grain yield was accounted for by the combined effect of environment and planting date (Tables 3 and 4). The response of coarse-to-fine ratio and grain 
yield to planting date depended on the environment. At high latitudes, delayed planting generally reduced kernel coarse-to-fine ratio well below standards for premiumgrade dry milling (i.e., Balcarce and Viedma; Tables 3 and 4). Industry requirements at these latitudes, however, were frequently attained with early plantings. Planting date effects lost relevance and consistency at low latitudes. The strategy of delayed plating as a way to stabilize grain yield (Maddonni, 2012) would not always be compatible for achieving kernel hardness grades demanded by the dry milling industry. These results are in accordance with the high proportion of maize for dry milling that is produced at low-latitude regions, where planting date management has a reduced effect on kernel hardness.

Radiation and air temperature effects were the main drivers for the observed variation in maize kernel coarseto-fine ratio and grain yield when considering that crop water demand was to a great extent fulfilled by complementing precipitation with irrigation. Kernel hardness in maize is influenced by the physiological condition of the crop during the reproductive period (Cirilo et al., 2011). In accordance, the integration of these climate variables in the estimation of potential photosynthetic source during crop reproductive period explained a great proportion $(37 \%)$ of the variation in kernel coarse-to-fine ratio across environments and planting dates (Fig. 5). The reduction in maize kernel coarse-to-fine ratio with delayed planting at high latitudes coincided with a marked decline of maize photosynthetic source during the reproductive period (Table 1).

Results from this study indicate the potential to generate predictive models for the effect of environment and agronomic management on maize kernel hardness based on ecophysiological variables. Kernel hardness depends on kernel composition (Chandrashekar and Mazhar, 1999). Proteins, particularly the zein fraction, influence maize kernel hardness (Robutti et al., 1997; Gerde et al., 2016). Further advances in the understanding of the effect of growing conditions on protein deposition to grain will be useful to model the effects of environment and agronomic management on kernel hardness.

Kernel coarse-to-fine ratio and grain yield were not associated across environments $\left(R^{2}=0.03, P=0.12\right)$. These results contrast with those reported by Eyhérabide et al. (2004), which showed a positive association between coarse-to-fine ratio and grain yield for different environments across the Argentinean maize-producing region. As previously discussed, kernel hardness is to a great extent dependent on crop physiological condition during the grain-filling period. Grain yield, on the other hand, is to a great extent related to the physiological condition of the crop around silking (Andrade et al., 1999), and these conditions are not always associated. Cirilo et al. (2011) reported that maize kernel hardness was incremented as a response to an increase in assimilate availability per kernel; thereafter, a reduction in kernel number due to crop growth restrictions around silking could increase photo-assimilate availability per kernel during the maize reproductive period. This scenario, for example, would reduce grain yield but increase kernel hardness. Overall, these results indicate that kernel hardness is not conditioned by grain productivity.

\section{CONCLUSIONS}

Results of this study show that hybrid can consistently affect kernel coarse-to-fine ratio and grain yield. Kernel coarseto-fine ratio and grain yield differences among the harder and softer hybrids increased as growing conditions favored increases in coarse-to-fine ratio and grain yield. Results from additional hybrids are needed to validate these findings. Results from this study also reveal the importance of growing conditions on maize kernel hardness. Planting date can have a large influence on kernel coarse-to-fine ratio depending on the environment. Delayed planting markedly reduced kernel coarse-to-fine ratio at high-latitude, shortseason locations. Much of the observed differences in maize kernel coarse-to-fine ratio due to environment and planting date were linked to crop potential photosynthetic source during the maize reproductive period. A clear understanding of the role of thermal and radiative conditions on kernel composition is needed to predict the effect of growing conditions on kernel hardness. This study involved a large set of experiments and provides highly relevant information to modelers progressing toward this prediction capacity. Overall, these results indicate that growing environment and crop management should be considered together with the hybrid in the design of maize production strategies oriented to end-use quality.

\section{Conflict of Interest}

The authors declare that there is no conflict of interest.

\section{Acknowledgments}

This work is in partial fulfillment of A. Cerrudo's doctoral thesis at FCA UNMdP and was funded by INTA (PNCYO 1127042) and the Universidad Nacional de Mar del Plata (AGR 451/14 and AGR 506/16).

\section{References}

Andrade, F.H., S.A. Uhart, and A. Cirilo. 1993. Temperature affects radiation use efficiency in maize. Field Crops Res. 32:17-25. doi:10.1016/0378-4290(93)90018-I

Andrade, F.H., C. Vega, S. Uhart, A. Cirilo, M. Cantarero, and O. Valentinuz. 1999. Kernel number determination in maize. Crop Sci. 39:453-459. doi:10.2135/cropsci1999.0011183X003 $9000200026 x$

Aramburu Merlos, F., J.P. Monzon, J.L. Mercau, M. Taboada, F.H. Andrade, A.J. Hall et al. 2015. Potential for crop production increase in Argentina through closure of existing yield gaps. Field Crops Res. 184:145-154. doi:10.1016/j. fcr.2015.10.001 
Bauer, P.J., and P.R. Carter. 1986. Effect of seeding date, plant density, moisture availability, and soil nitrogen fertility on maize kernel breakage susceptibility. Crop Sci. 26:1220-1226. doi:10.2135/cropsci1986.0011183X002600060030x

Blandino, M., D. Sacco, and A. Reyneri. 2013. Prediction of the dry milling performance of maize hybrids through hardness-associated properties. J. Sci. Food Agric. 93:1356-1364. doi:10.1002/jsfa.5897

Bonelli, L., J.P. Monzon, A. Cerrudo, R.H. Rizzalli, and F.H. Andrade. 2016. Maize grain yield components and sourcesink relationship as affected by the delay in sowing date. Field Crops Res. 198:215-225. doi:10.1016/j.fcr.2016.09.003

Brun, E.L., and J.W. Dudley. 1989. Nitrogen response in the USA and Argentina of corn populations with different proportions of flint and dent germplasm. Crop Sci. 29:565-569. doi:10.2135/cropsci1989.0011183X002900030003x

Caffera, R.M., and E.H. Berbery. 2006. La Plata Basin climatology. In: V. Barros, R. Clarke, and P. Silva Díaz, editors, Climate change in the Plata Basin. Centro de Investigaciones del Mar y la Atmosfera, Buenos Aires. p. 16-32.

Chandrashekar, A., and H. Mazhar. 1999. The biochemical basis and implications of grain strength in sorghum and maize. Cereal Sci. 30:193-207. doi:10.1006/jcrs.1999.0264

Cirilo, A.G., M. Actis, F.S. Borrás, J.L. Robutti, F.H. Andrade, and O.R. Valentinuz. 2011. Crop management affects dry milling quality of flint maize kernels. Field Crops Res. 122:140-150. doi:10.1016/j.fcr.2011.03.007

Cirilo, A.G., and F.H. Andrade. 1994. Sowing date and maize productivity: II. Kernel number determination. Crop Sci. 34:1044-1046. doi:10.2135/cropsci1994.0011183X00340004 $0038 x$

De Mendiburu, F. 2009. Agricolae: Statistical procedures for agricultural research. R package version 1.0-7. R Foundation for Statistical Computing. http://CRAN.R-project.org/ package $=$ agricolae (accessed 8 May 2017).

Dombrink Kurtzman, M.A., and J.A. Bietz. 1993. Zein composition in hard and soft endosperm of maize. Cereal Chem. 70:105-108.

Duarte, A.P., S.C. Mason, D.S. Jackson, and J.C. Kiehl. 2005. Grain quality of Brazilian maize genotypes as influenced by nitrogen level. Crop Sci. 45:1958-1964. doi:10.2135/cropsci2004.0587

Eyhérabide, G.H., J.L. Robutti, N.M. Percibaldi, D.A. Presello, and M.d.P. Álvarez. 2004. Association between grain yield and endosperm hardness in maize cultivars. Maydica 49:319326.

Finlay, K., and G. Wilkinson. 1963. The analysis of adaptation in a plant-breeding program. Aust. J. Agric. Res. 14:742-754. doi:10.1071/AR9630742

Fox, G., and M. Manley. 2009. Hardness methods for testing maize kernels. J. Agric. Food Chem. 57:5647-5657. doi:10.1021/ jf900623w

Gerde, J.A., S. Tamagno, J.C. Di Paola, and L. Borrás. 2016. Genotype and nitrogen effects over maize kernel hardness and endosperm zein profiles. Crop Sci. 56:1225-1233. doi:10.2135/cropsci2015.08.0526

GraphPad. 2007. GraphPad Prism 5.0. GraphPad Software, San Diego, CA.

Hall, A.J., C.M. Rebella, C.M. Ghersa, and J.P. Culot. 1992. Field-crops systems of the Pampas. In: C.J. Pearson, editor, Field crop ecosystem. Elsevier, Amsterdam. p. 413-450.
Holding, D.R., and B.A. Larkins. 2006. The development and importance of zein protein bodies in maize endosperm. Maydica 51:243-254.

Hunter, J.L., D.M. TeKrony, D.F. Miles, and D.B. Egli. 1991. Corn seed maturity indicators and their relationship to uptake of carbon-14 assimilate. Crop Sci. 31:1309-1313. doi:10.2135/ cropsci1991.0011183X003100050045x

INASE. 2016. Catálogo nacional de cultivares de maíz. Instituto Nacional de Semillas de la República Argentina, Buenos Aires, Argentina. http://www.inase.gov.ar (accessed 29 Oct. 2016).

Kniep, K.R., and S.C. Mason. 1991. Lysine and protein content of normal and opaque-2 maize grain as influenced by irrigation and nitrogen. Crop Sci. 31:177-181. doi:10.2135/cropsci1991. 0011183X003100010040x

Lee, K.M., T.J. Herrman, S.R. Bean, D.S. Jackson, and R. Lingenfelser. 2007. Classification of drymilled maize grit yield groups using quadratic discriminant analysis and decision tree-algorithm. Cereal Chem. 84:152-161. doi:10.1094/ CCHEM-84-2-0152

Louis-Alexandre, A., C. Mestres, and J. Faure. 1991. Measurement of endosperm vitreousness of corn: A quantitative method and its application to African cultivars. Cereal Chem. 68:614-617.

Luque, S.F., A.G. Cirilo, and M.E. Otegui. 2006. Genetic gains in grain yield and related physiological attributes in Argentine maize hybrids. Field Crops Res. 95:383-397. doi:10.1016/j. fcr.2005.04.007

Maddonni, G.A. 2012. Analysis of the climatic constraints to maize production in the current agricultural region of Argentina-a probabilistic approach. Theor. Appl. Climatol. 107:325-345. doi:10.1007/s00704-011-0478-9

Magdoff, F.R., D. Ross, and J. Amadon. 1984. A soil test for nitrogen availability to corn. Soil Sci. Soc. Am. J. 48:1301-1304. doi:10.2136/sssaj1984.03615995004800060020x

Melchiori, R., O. Paparotti, and W. Paul. 1996. Diagnóstico de la fertilización nitrogenada de maíz: Nitratos en pre-escardillada. Serie de Extensión EEA INTA Paraná 11:23-27.

Mistrorigo, D., and O. Valentinuz. 2004. Fertilización de maíz en siembra directa en suelos molizoles y vertisoles de Entre Ríos. Rev. Cient. Agrop. 8:99-107.

Monteith, J.L. 1972. Solar radiation and productivity in tropical ecosystems. J. Appl. Ecol. 9:747-766. doi:10.2307/2401901

Moscatelli, G., L.A. Luters, and L.A. Gómez. 2001. Niveles de disponibilidad y reservas de potasio en Argentina. In: R.J.H. Magen and R.S. Lavado, editors, El potasio en sistemas agrícolas argentinos. International Potash Institute-Instituto Nacional de Tecnología Agropecuaria, Castelar, Buenos Aires. p. 13-19.

NASA-POWER. 2017. NASA surface meteorology and solar energy. NASA. http://power.larc.nasa.gov/ (accessed 5 June 2017)

Orthoefer, F.J., G. Eastman, P.J. List, P. White, and L.A. Johnson. 2003. Corn oil: Composition, processing, and utilization. In: P. White and L.A. Johnson, editors, Corn: Chemistry and technology. Am. Assoc. Cereal Chem., St. Paul, MN. p. 671693.

Pagani, A., H.E. Echeverria, and F.H. Andrade. 2009. Characterization of corn nitrogen status with a greenness index under different availability of sulfur. Agron. J. 101:315-322. doi:10.2134/agronj2008.0136

PAS. 2016. Panorama agrícola semanal. Bolsa de Cereales Argentina. http://www.bolsadecereales.com/pas/ (accessed 28 May 2017) 
Paulsen, M.R., S.A. Watson, and M. Singh. 2003. Measurement and maintenance of corn quality. In: P.J. White and L.A. Johnson, editors, Corn: Chemistry and technology. 2nd ed. Am. Assoc. Cereal Chem., Saint Paul, MN. p. 159-219.

Peterson, C.J., R.A. Graybosch, P.S. Baenziger, and A.W. Grombacher. 1992. Genotype and environment effects on quality characteristics of hard red winter wheat. Crop Sci. 32:98-103. doi:10.2135/cropsci1992.0011183X003200010022x

Pomeranz, Y., G.E. Hall, Z. Czuchajowska, and F.S. Lai. 1986. Test weight, hardness and breakage susceptibility of yellow dent corn hybrids. Cereal Chem. 63:349-351.

Ritchie, S.W., J.J. Hanway, and G.O. Benson. 1997. How a corn plant develops. Iowa State Univ. Coop Ext. Serv. Spec. Rep. 48. Iowa State Univ., Ames.

Robutti, J.L., F.S. Borrás, and G.H. Eyhérabide. 1997. Zein composition of mechanically separated coarse and fine portions of maize kernels. Cereal Chem. 74:75-78. doi:10.1094/ CCHEM.1997.74.1.75

Robutti, J.L., F.S. Borrás, M.E. Ferrer, N.M. Percibaldi, and C.E. Knuston. 2000. Evaluation of quality factors in Argentine maize races. Cereal Chem. 77:24-26. doi:10.1094/ CCHEM.2000.77.1.24
Sainz Rozas, H., H.E. Echeverría, G.A. Studdert, and G. Domínguez. 2000. Evaluation of the presidedress soil nitrogen test for no-tillage maize fertilized at planting. Agron. J. 92:11761183. doi:10.2134/agronj2000.9261176x

Serignese, A.D., and F.E. Pescio. 1995. Maíz colorado duro. Una alternativa interesante. Serie Divulgación N 1. Dirección de Producción Agrícola Secretaría de Agricultura, Ganadería y Pesca, Mexico City. p. 1-36.

Tamagno, S., I.A. Greco, H. Almeida, and L. Borrás. 2015. Physiological differences in yield related traits between flint and dent Argentinean commercial maize genotypes. Eur. J. Agron. 68:50-56. doi:10.1016/j.eja.2015.04.001

Tamagno, S., I.A. Greco, H. Almeida, J.C. Di Paola, F.M. Ribes, and L. Borrás. 2016. Crop management options for maximizing maize kernel hardness. Agron. J. 108:1561-1570. doi:10.2134/agronj2015.0590

van Wart, J., P. Grassini, and K.G. Cassman. 2013. Impact of derived global weather data on simulated crop yields. Glob. Change Biol. 19:3822-3834. doi:10.1111/gcb.12302

Wu, Y.V. 1992. Corn hardness as related to yield and particle size of fractions from a micro hammer-cutter mill. Cereal Chem. 69:343-347. 